University of Nebraska - Lincoln

DigitalCommons@University of Nebraska - Lincoln

Publications, Agencies and Staff of the U.S.

Department of Commerce

U.S. Department of Commerce

2009

\title{
From Captivity to the Wild and Back: An Attempt to Release Keiko the Killer Whale
}

M. Simon

Greenland Institute of Natural Resources, P. O. Box 570, 3900 Nuuk, Greenland

M. B. Hanson

NOAA Fisheries

L. Murrey

Moeller Design and Development

J. Tougaard

National Environmental Research Institute

F. Ugarte

Greenland Institute of Natural Resources

Follow this and additional works at: https://digitalcommons.unl.edu/usdeptcommercepub

Part of the Environmental Sciences Commons

Simon, M.; Hanson, M. B.; Murrey, L.; Tougaard, J.; and Ugarte, F., "From Captivity to the Wild and Back: An Attempt to Release Keiko the Killer Whale" (2009). Publications, Agencies and Staff of the U.S.

Department of Commerce. 33.

https://digitalcommons.unl.edu/usdeptcommercepub/33

This Article is brought to you for free and open access by the U.S. Department of Commerce at DigitalCommons@University of Nebraska - Lincoln. It has been accepted for inclusion in Publications, Agencies and Staff of the U.S. Department of Commerce by an authorized administrator of DigitalCommons@University of Nebraska - Lincoln. 


\title{
Marine Mammal Science
}

Early View, Date: March 2009

MARINE MAMMAL SCIENCE, **(*): ***_***(*** 2009)

(C) 2009 by the Society for Marine Mammalogy

DOI: $10.1111 /$ j.1748-7692.2009.00287.x

\section{From captivity to the wild and back: An attempt to release Keiko the killer whale}

\author{
M. SIMON \\ Greenland Institute of Natural Resources, \\ P. O. Box 570, \\ 3900 Nuuk, Greenland \\ and \\ Department of Biological Sciences, \\ University of Aarhus, \\ C. F. Møllers Allé, Build. 1131, \\ 8000 Aarhus C, Denmark \\ E-mail: masi@natur.gl \\ M. B. HANSON \\ NOAA Fisheries, \\ 2725 Montlake Boulevard East, \\ Seattle, Washington 98112-2097, U.S.A. \\ L. Murrey \\ Moeller Design and Development, \\ 620 S Industrial Way, \\ Seattle, Washington 98108, U.S.A.

\section{J. TOUGAARD} \\ National Environmental Research Institute, \\ University of Aarhus, \\ Frederiksborgvej 399, \\ P. O. Box 358, DK-4000 Roskilde, Denmark \\ F. UGARTE \\ Greenland Institute of Natural Resources, \\ P. O. Box 570 , \\ 3900 Nuuk, Greenland
}

A number of cetaceans have been released into the wild, with research or the improved welfare of the individuals in question as the main goal. In a few cases, releases have been monitored with methods such as telemetry or photo-identification (Gales and Waples 1993, Veit et al. 1997, Wells et al. 1998, Reynolds et al. 2000). As a rule, the animals released successfully into the wild had been captive for relatively short periods of time (e.g., 2 yr, Wells et al. 1998), were held in sea pens rather than concrete tanks, and some were released in the company of conspecifics (Veit et al. 1997, Wells et al. 1998). We describe here the last phases of a project aimed at releasing a single killer whale that had been captured as a calf, raised in tanks and kept isolated from conspecifics during most of his life. 
The released killer whale, known as Keiko, was a male born into a wild group of killer whales in Icelandic waters. He was captured in 1979 near Vestmannaeyjar, Iceland, approximately $2 \mathrm{yr}$ old, determined from tooth growth layers. After $6 \mathrm{yrs}$ with other killer whales in tanks in Iceland and Canada, he was sold to an amusement park in Mexico. From 1985 to 1996, Keiko lived and performed in a small pool in Mexico City, without contact with other killer whales (bottlenose dolphins were kept periodically in the same tank). In 1996, as the first step of a program to return Keiko to the wild, he was transported to a large concrete enclosure in Oregon. In 1998, he was moved to a bay pen in Klettsvik, a natural bay in the archipelago of Vestmannaeyjar, Iceland, where he received training aimed at a release to the wild (Anonymous 2000).

During the summers of 2000, 2001, and 2002, Keiko was trained to follow his caretakers' boat and take open ocean swims. Each summer, he spent several days in the proximity of wild killer whales that seasonally inhabit the waters around Vestmannaeyjar to feed on summer-spawning herring (Sigurjónsson et al. 1988; Jakobsson and Stefánsson 1999; Schorr 2002; Simon et al. 2005, 2006, 2007). Biopsies of the wild killer whales were taken during 2000-2001 (Schorr 2002). DNA analyses have shown that there are at least two genetic types of killer whales in the area and that Keiko shared a genotype with some of the wild whales (Hoelzel 2002). In the summer of 2002, as in previous years, Keiko was led to waters off Vestmannaeyjar, Iceland. He experienced minimal human contact for approximately $1 \mathrm{mo}$, while following wild killer whales. Subsequently, he spent another month swimming from southern Iceland to Norway (Fig. 1). Keiko was taken once more under human care

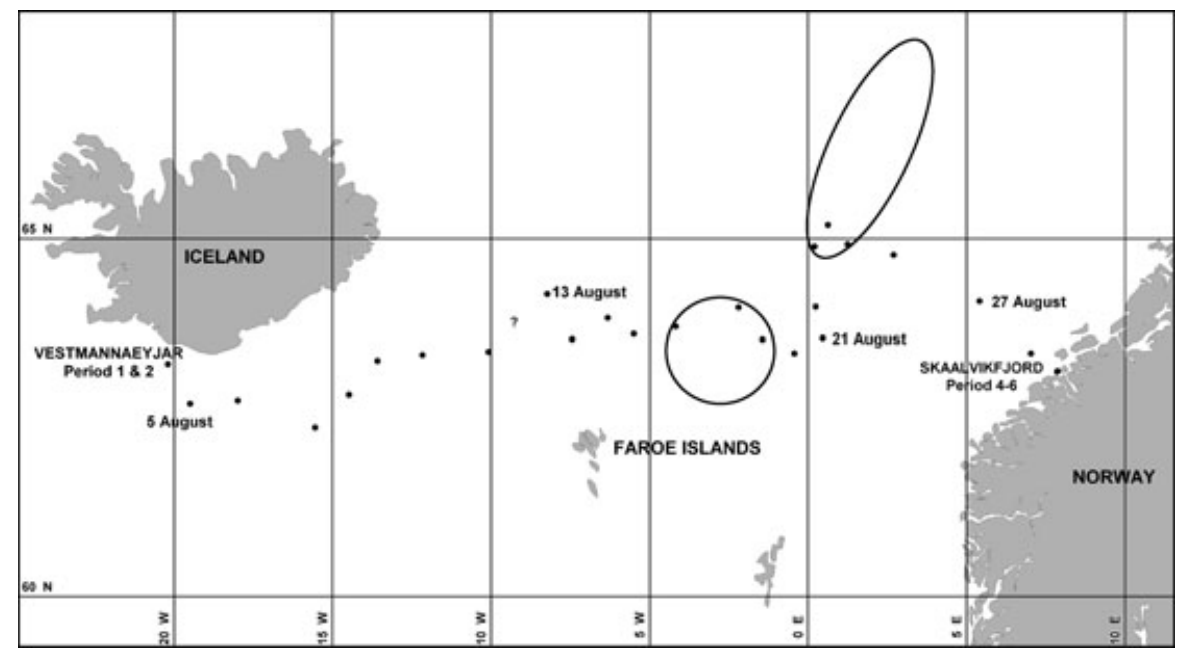

Figure 1. Study area, where the location of the whale is marked during the six periods of the release. The positions given by the satellite tag, during travel from Iceland to Norway in period 3 are marked. The approximate core areas for mackerel in the summer of 2002 are marked with open circles (Anonymous 2003). 


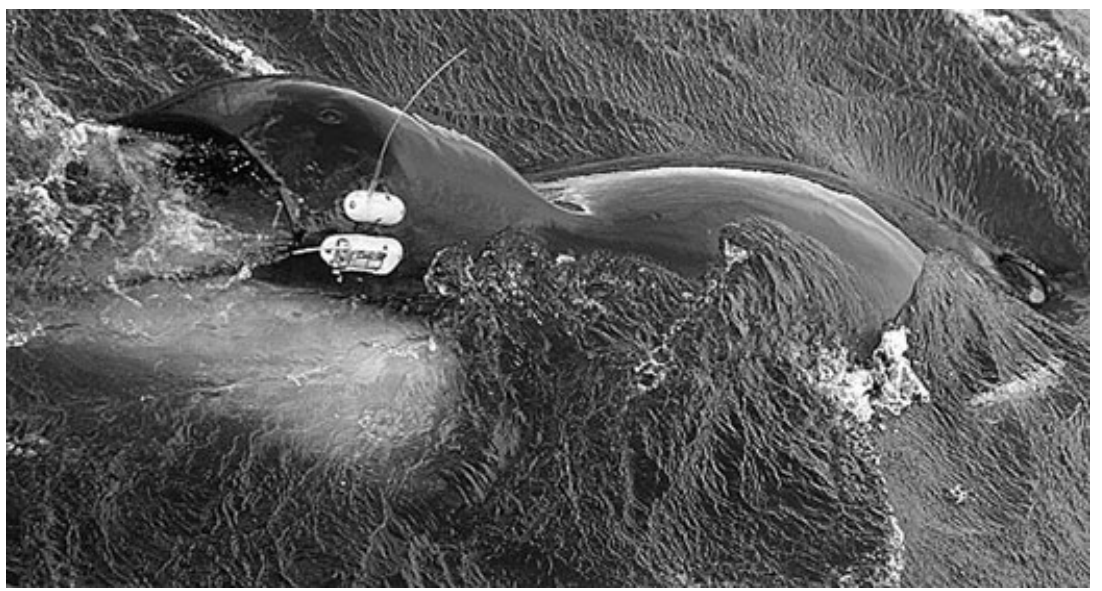

Figure 2. Keiko after arriving in Norway with the VHF tag (on top) and SDR tag (below) mounted to his dorsal fin. (Photo by Thorbjörg Kristjansdottir.)

in Norway and a free access enclosure was constructed in Skålvikfjorden, where he remained until his death in December 2003.

\section{MONITORING AND INSTRUMENTATION}

Immediately before the first open ocean swim of 2002, a VHF transmitter (ATS model 201) and a satellite-linked time-depth recorder, SDR (Wildlife Computers SDR-T16, Redmond, WA) were attached to the dorsal fin. The VHF tag allowed us to track Keiko in the field $24 \mathrm{~h}$ a day, while the SDR provided a few daily positions and a summary of the diving behavior. The positions provided were obtained within a few hours in the morning and thus did not provide data on Keiko's movements during the day. Therefore we selected the best-quality daily position (Fig. 1). The SDR-T16 tags collect dive data over 6-h time blocks and are transmitted as three different summary histograms of dive depth, dive duration, and time at depth. During a dive, the tag sampled depth every $10 \mathrm{~s}$ and logged information into one of 14 intervals (6-26, 26-50, 50-76, 76-100, 100-126, 126-150, 150-176, 176-200, 200-250, 250-300, 300-350, 350-400, 400-450, and >450 m). The tag electronics were over-molded in a urethane housing to fit the irregular surface of Keiko's dorsal fin. After 2 mo of attachment, the tags were inspected visually and there were no signs of tag migration or damage of the tissue surrounding the tags (Fig. 2).

\section{TIMELINE OF RELEASE EFFORT}

For purposes of analysis, the study was divided into six periods, based on Keiko's location and contact with humans and wild killer whales (Table 1). During periods 1 and 2, Keiko was off the archipelago of Vestmannaeyjar and adjacent waters, in southern Iceland and periodically observed from a small sailboat. In order 
Table 1. The six periods of the study.

\begin{tabular}{llll}
\hline \hline Period & \multicolumn{1}{c}{ Date (2002) } & \multicolumn{1}{c}{ Location } & \multicolumn{1}{c}{ Comments } \\
\hline 1 & 7 July-16 July & Vestmannaeyjar & First period among wild whales \\
2 & 17 July-4 Aug. & Vestmannaeyjar & Second period among wild whales \\
3 & 5 Aug.-31 Aug. & Iceland to Norway & Eastward movement \\
4 & 1 Sept.-3 Sept. & Skålvikfjorden & Contact with people \\
5 & 4 Sept.-11 Sept. & Inner Skålvikfjorden & Reduced activity \\
6 & 12 Sept.-29 Sept. & Skålvikfjorden area & Behavioral control \\
\hline
\end{tabular}

to reduce the influence of human contact, visual observations were restricted to a few close approaches per day that allowed us to assess Keiko's behavior and physical condition. If Keiko approached the tracking boat, the crew went below deck or otherwise hid from view until he lost interest. The position of the tracking boat, the time, date, estimated direction and distances to Keiko and to the wild whales, as well as the behavior of the wild whales, were recorded approximately every $15 \mathrm{~min}$. Period 1 and 2 are divided by Keiko swimming back to the bay pen, being fed and receiving human care before being brought back to the wild killer whales. During period 3, he swam from Vestmannaeyjar to Skålvikfjorden, Norway. In period 4, he interacted with people in the waters of Skålvikfjorden. During period 5, he remained in a relatively small area and in period 6, professional caretakers took Keiko for regular swims from inner Skålvikfjorden into nearby waters. Period 6 extended beyond 29 September 2002, the last day included in this analysis.

\section{Period 1}

Beginning on 7 July, Keiko spent seven consecutive days in the proximity of wild killer whales. The wild whales were divided into groups that joined, split, and moved in loose coordination, traveling around midnight and returning to forage in specific shallow areas during daytime (a killer whale group was defined as a cluster of animals in close proximity to each other that appeared to be independent to other killer whale groups in the area). Foraging was identified by the arching of a killer whale's body before diving, debilitated fish or fish parts at the surface and birds taking fish from the surface (Simon et al. 2007). Keiko switched between different groups of wild killer whales, often remaining on the periphery, at distances of 100-300 m, with his head pointing toward the closest whales. During this period, Keiko was seen either floating motionless ("logging") or swimming slowly without arching his body. No arching or other behaviors typical for cetaceans prior to dives were observed. Keiko became separated from the wild whales after midnight on 15 July. Later that day, at 10:10, he swam back into the bay pen in Klettsvik, where he remained until the afternoon of 17 July. A stomach sample taken with a large tube was analyzed using a stereomicroscope. The sample consisted of a transparent, slimy liquid without any trace of food remains, showing that Keiko did not eat before entering the bay pen. ${ }^{1}$

\footnotetext{
${ }^{1}$ Personal communication from Gísli A. Víkingsson, Marine Research Institute, P. O. Box 1390, 121 Reykjavík, Iceland, e-mail: gisli@hafro.is, 5 September 2008.
} 


\section{Period 2}

Keiko was again led into open water on 17 July and was observed following wild whales during the period 17 July-24 July and again during 27 July-1 August (observations were interrupted on 25 and 26 July due to bad weather). As during period 1, Keiko followed wild killer whales that were split into three to five groups, which moved and interacted in loose coordination inside an area with a diameter of approximately $30 \mathrm{~km}$. A second stomach sample was taken on 23 July, after Keiko was led away from a fishing boat. As with the previous sample, there was only a transparent, slimy liquid and no food remains were observed using a stereomicroscope. During period 2, the distance between Keiko and the wild whales progressively decreased. By 27 July he was regularly seen closer than $30 \mathrm{~m}$ from the closest wild whale. A brief physical interaction was witnessed on 30 July, when Keiko dove among foraging whales and surfaced in very close proximity to three adult males and at least two females or immature males. There was a splash from the tail of one of the wild whales, which was swimming ventral side up, with his head below Keiko, while he was at the surface. The splash was accompanied by a "startle" reaction from Keiko who swam to the tracking boat, while one of the female/juvenile whales surfaced after him. This was the only time Keiko was seen diving among killer whales and the only physical interaction observed. On 27 July, Keiko was seen arching his back before diving and then later breaking the surface of the water with his rostrum, as if ascending vertically. On 29 July, on two occasions, Keiko was seen raising his fluke up before diving, indicating a vertical descent.

\section{Period 3}

Keiko spent the majority of period 3 offshore, swimming from Iceland to Norway. There was no visual contact between 2 August and 29 August when he was tracked with the satellite transmitter. As his track soon veered off the suspected migration routes of killer whales between southern and eastern Iceland (Sigurjónsson and Leatherwood 1988), Keiko might have been alone during this period although due to the lack of visual contact we cannot be certain. On 30 August, Keiko was observed close to Kristianssund, Norway, a few meters from shore, in very shallow water. His physical appearance was healthy: the skin color and texture seemed normal, he did not look emaciated, and the tissue around the tag showed no signs of tag migration or infection. In addition, he seemed to move more actively than observed during periods 1 and 2 .

\section{Period 4}

Keiko followed a small open boat with local people that were out for a pleasure fishing trip. He followed the boat into its home place in Skålvikfjorden and interacted with local people from 1 September to 3 September. During daylight hours, a crowd, from land and boats, was almost constantly soliciting his attention, trying to touch him or swim with him. In the beginning of this period, Keiko often initiated the 
interactions and swam actively from one group of people to another. At about 1900 on 3 September, Keiko was seen logging and swimming slowly toward the inner parts of Skålvikfjorden. At the time of the observation, several small boats were following and surrounding him on four sides, with the passengers hitting the boat hulls, trying to attract his attention. Keiko was notably less active than earlier in this period.

\section{Period 5}

During 4 September, Keiko placed himself below and between two skiffs tied to a floating bridge. During daylight hours, until 9 September, he remained almost motionless close to this spot. On at least two occasions, people fed Keiko with small amounts of fish. On the afternoon of 6 September, the local animal welfare authorities issued a legislation prohibiting people to touch, feed, or approach Keiko closer than $50 \mathrm{~m}$, whether from land or by sea. Keiko's caretakers started feeding him again on 8 September. In order to raise the activity level of the passive whale, caretakers took Keiko for short swims with a boat within the waters of inner Skålvikfjorden on 9 September.

\section{Period 6}

During period 6, Keiko's physical activity was systematically encouraged by his trainers and he was taken for longer swims into Skålvikfjorden and adjacent waters. During this period, Keiko's activity increased to levels similar to the years he spent in Klettsvik bay pen in Iceland before the release. Period 6 extended beyond 29 September 2002, the last day included in this analysis. Keiko stayed in the free access bay pen in Skålvikfjorden. Usually he had access to the open water and he swam alone outside the bay pen, returning by himself. Keiko died in December 2003 apparently from pneumonia, approximately $26 \mathrm{yr}$ old.

\section{Dive BeHAVIOR}

Two hundred and nine dive-depth histograms were received, containing summed information from a total of 1,264 h. Of 7,541 dives recorded, 93.4\% were between 6 and $26 \mathrm{~m}$ deep. Of the dives deeper than $26 \mathrm{~m}, 98 \%$ occurred during periods 2 and 3. There were significantly fewer dives/h during period 5 compared to periods 1 , 2, 3, and 4 (Tukey's Studentized range test, $P<0.01$ ). There were also fewer dives/h during period 5 than during period 6 (Table 2), but this difference was not significant. The largest number of dives/h deeper than $50 \mathrm{~m}$ was recorded on $29 \mathrm{July}$. This coincides with the observed fluking in the surface before diving. The deepest recorded dive of $72 \mathrm{~m}$ occurred on 3 August, at the end of period 2 (Table 2). During all periods, Keiko spent more than $80 \%$ of the time in the upper $4 \mathrm{~m}$ of the water column. 
Table 2. Maximum dive depth during the six periods of the study where $n$ is the number of 6-h periods and the number of dives per hour during all six periods. A dive is defined as $>6 \mathrm{~m}$.

\begin{tabular}{lcccr}
\hline \hline Period & $\begin{array}{c}\text { Average maximum } \\
\text { depth (SD) }\end{array}$ & $\begin{array}{c}\text { Maximum depth } \\
\text { range }(n)\end{array}$ & $\begin{array}{c}\text { Average number of } \\
\text { dives/h(SD) }\end{array}$ & $\begin{array}{c}\text { Range of } \\
\text { dives/h }(n)\end{array}$ \\
\hline 1 & $17.7 \mathrm{~m}(7.6)$ & $12-32 \mathrm{~m}(7)$ & $6.3(4.4)$ & $0-18(36)$ \\
2 & $53.0 \mathrm{~m}(16.4)$ & $32-72 \mathrm{~m}(4)$ & $7.6(3.0)$ & $0.3-13.7(37)$ \\
3 & $45.3 \mathrm{~m}(10.3)$ & $36-64 \mathrm{~m}(6)$ & $7.9(4.2)$ & $0-20.2(66)$ \\
4 & $16.0 \mathrm{~m}^{\mathrm{a}}$ & $16 \mathrm{~m}(1)$ & $5.9(6.1)$ & $0-16.3(9)$ \\
5 & $12.0 \mathrm{~m}(9.1)$ & $4-28 \mathrm{~m}(6)$ & $0.1(0.2)$ & $0-0.7(18)$ \\
6 & $12.8 \mathrm{~m}(6.5)$ & $0-24 \mathrm{~m}(10)$ & $3.1(3.6)$ & $0-14.8(45)$ \\
\hline
\end{tabular}

${ }^{\mathrm{a}}$ Only one status message was received for period 4.

One hundred and ninety-one dive duration histograms were received, which summarize $1,146 \mathrm{~h}$. The dive-duration intervals are: $0-1,1-3,3-5$, and $>5 \mathrm{~min}$. There were on average significantly more dives with durations of $0-1$ min during period 4 than in the other periods. The number of dives lasting $0-1$ min during period 5 was lower than in the other periods, but this difference was not significant. The average number of dives with durations of 1-3 min was significantly lower during period 5 than in all other periods except period 6 (Tukey's Studentized range test, $P<0.01$ ). There were significantly more long dives ( $>3 \mathrm{~min}$ ) during periods 2 and 3 compared to the other periods (Tukey's Studentized range test, $P<0.01$ ).

Two hundred and twenty-three time-at-depth histograms were received, summarizing 1,338 h. There was no significant difference in how much time Keiko spent at 6-26 m among the different periods (Nonparametric one-way ANOVA, $F=3.36$, $\mathrm{df}=5, P>0.05$ [Barnard et al. 2001]). Keiko spent significantly more time at 26-50 m during period 2 than during all other periods, with the exception of period 3 (Tukey's Studentized range test, $P<0.01$ ). The diving behavior during the most active periods were compared to the dive data presented by Schorr et al. (2001), who deployed eight suction-cup attached time-depth recorders on wild killer whales off Vestmannaeyjar (202 h), in summer 2000. Average number of dives per hour and average duration of dives, for dives longer than $1 \mathrm{~min}$, were compared with daytime data from Keiko collected in periods 2 and 3. The average duration of dives was estimated from dive duration histograms, excluding the $0-1 \mathrm{~min}$ bin and assuming that the average duration of dives in each bin was the center of the bin range.

Keiko made fewer dives $>1$ min than did the wild killer whales from Vestmannaeyjar. However, there was no significant difference between Keiko and the wild whales in the duration of these dives (Table 3). When looking at the different depth intervals of dives longer than $1 \mathrm{~min}$, Keiko dove more often than the wild whales to depths of 6-26 m, but less often than the wild whales to depths $>26 \mathrm{~m}$ (Table 3). Schorr et al. (2001) noted that the wild killer whales off Vestmannaeyjar spent an average of $76 \%$ of their time in the top $10 \mathrm{~m}$ of the water column. In comparison, Keiko spent more than $80 \%$ of the time in the upper $4 \mathrm{~m}$. 
Table 3. Number of dives per hour and dive duration, for dives longer than $1 \mathrm{~min}$, of wild killer whales $(n=202 \mathrm{~h})$. The data on Keiko's dive behavior include periods 2 and 3, minus time block 2100-0300. Average number of dives per hour for the four depth intervals for wild killer whales ( $n=5.5 \mathrm{~h}$, Schorr $e$ al. 2001) and Keiko ( $n=468 \mathrm{~h}$ from periods 2 and 3).

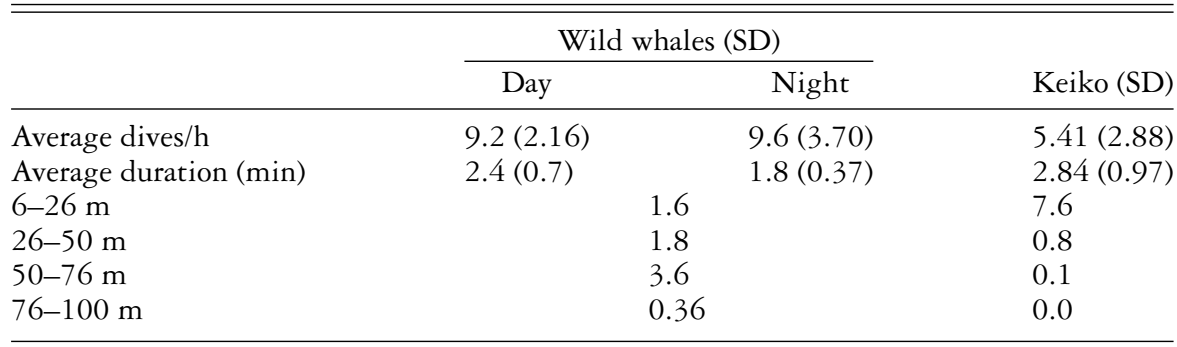

\section{KEIKO's BEHAVIOR AMONG WILD WHALES}

During the initial efforts to release Keiko into the wild in 2000 and 2001, he and the wild killer whales seldom approached and often moved away from one another. In contrast, Keiko followed the wild killer whales shortly after first being led to them in 2002 and the wild whales seemed to tolerate his presence. The distance between Keiko and the wild whales diminished gradually, and one physical interaction was observed close to the end of period 2. The fact that Keiko was observed to follow some of the same individuals for several weeks during 2002, and that some of these same individuals were present during 2000 and 2001 (photographic data, unpublished), suggest that a mutual acclimatization may have facilitated a growing familiarity between Keiko and these particular wild killer whales. This process seemed to be ongoing at the time of the last visual observation off Vestmannaeyjar in 2002. However, keeping in mind that limited visual contact did not allow drawing definitive conclusions, the fact that Keiko was usually seen either on the periphery of the wild whale groups, or logging at various distances from them, suggests that he was not socially integrated with the wild whales at the time of the last visual observation.

\section{Did KeIKo FeED?}

Prior to summer 2002, Keiko's diving performance was modest, with maximum recorded dive depths shallower than $35 \mathrm{~m} .{ }^{2}$ During summer 2002, the diving profile evolved from relatively short and shallow dives during period 1, to deeper and longer dives in periods 2 and 3. The increased diving activity recorded during period 2 corresponds well with observations of Keiko performing behaviors characteristic of deep dives, such as arching the body and lifting the flukes before diving. This

\footnotetext{
${ }^{2}$ Personal communication from Jeff Foster, Marine Research Consultants LLC, 2420 Nellita Road NW, Seabeck, WA 98380, U.S.A., e-mail: jefffoster13@yahoo.com, June 2001.
} 
evolution caused Keiko's most active diving profile to resemble the profiles observed for wild Icelandic killer whales. Because he made shallower and less frequent dives than wild killer whales, and due to the failure to observe him consistently diving among feeding wild whales, it seems unlikely that Keiko actively participated in the wild whales' cooperative hunts. However, the increase in depth and duration of Keiko's dives during period 2 suggests that he nevertheless may have been able to obtain food while among the feeding wild whales. Observations of stunned herring at the surface, as well as underwater recordings, indicate that Icelandic killer whales immobilize herring by hitting the fish schools with the underside of their flukes, as Norwegian killer whales do (Simon et al. 2005). Underwater observations of Norwegian killer whales feeding showed that a considerable number of immobilized herring were not taken by the killer whales that debilitated them, but by other killer whales, fish, or sea birds (Similä and Ugarte 1993). A similar situation seems to take place when Icelandic killer whales hunt herring (Simon et al. 2005). Though Keiko was not seen feeding on live herring, it is possible that he could have fed on already stunned fish without diving as deep or as often as the wild killer whales. However, it is unlikely that he consumed any significant amount of food shortly before 15 July and 23 July, when samples of his stomach contents were obtained. During period 3 , while traveling to Norway, Keiko moved on average $71.8 \mathrm{~km} / \mathrm{d}$, calculated from straight-line connections between satellite locations. The mean swimming speed of undisturbed resident killer whales in British Columbia was $5.19 \mathrm{~km} / \mathrm{h}, \mathrm{SD} 2.52 \mathrm{~km} / \mathrm{h}$ (Kruse 1991). Assuming Keiko moved with an average speed of $5 \mathrm{~km} / \mathrm{h}$, which allows for low energy consumption (Yazdi et al. 1999), he would have been capable of traveling this distance of $71.8 \mathrm{~km} / \mathrm{d}$ in $14.4 \mathrm{~h}$, resulting in a surplus of nearly $10 \mathrm{~h} / \mathrm{d}$. This can be interpreted in two ways: either he did not swim in a straight line between satellite positions, or he spent time engaged in other activities such as resting or foraging. The relatively high diving activity during period 3 indicates that Keiko performed behaviors other than resting or horizontal traveling during this long trip, including the possibility that he was foraging. Of the potential prey species that Keiko was likely to encounter, blue whiting and squid are found at depths deeper than $200 \mathrm{~m}$ during daylight, outside his observed diving range. However, these potential prey items ascend to the surface at night and it is therefore possible that they were intermittently available. Mackerel seem a likely prey candidate during period 3, since Keiko spent approximately $10 \mathrm{~d}$ in an area with a high concentration of this species, which can be found within the upper $20 \mathrm{~m}$ of the water column throughout the day and night (Fig. 1, Anonymous 2003). The fact that no difference was detected in the diving behavior between the times Keiko spent inside and outside of the mackerel grounds may suggest that he did not take advantage of this prey. However, as the mackerel are available in the top of the water column during the day, Keiko might have captured this fish without significantly changing his diving behavior. It is possible that Keiko did not feed at all during the time he was independent of human care. Newly captured killer whales are able to live without food for several weeks before eating dead fish (Hoyt 1998). However, this seems unlikely given the healthy appearance and behavior of Keiko when he was first observed in Norway, as 
well as the fact that a veterinarian, based on girth measurements, blood samples and photographs, concluded that the whale had fed (Cornell 2002).

\section{Human IMPACT ON KeIKO’s BeHAVIOR}

Before July 2002, Keiko had no contact with the tracking boat and, as a rule, had very little contact with her crew. During periods 1 and 2, the tracking boat spent $18 \mathrm{~d}$ at sea tracking Keiko. Keiko approached the tracking boat on 16 occasions, with durations ranging from 2 min to $<2 \mathrm{~h}$. During these approaches, Keiko would either swim close to the boat or log with his head almost touching the hull. On two occasions, repeated loud vocalizations attributed to Keiko were heard below deck.

During periods 1 and 2, Keiko approached the caretakers' boat on the two occasions when this boat was out of the harbor. The first time was on 8 July, when Keiko had been on his own for one day, during which the caretakers' boat had been drifting with the engine off. When the caretakers' boat switched on the engine for the first time, Keiko, who was $2 \mathrm{nmi}$ away, homed straight for it and remained in its proximity for $57 \mathrm{~h}$. Keiko approached the caretakers' boat a second time, during a crew change on 22 July, and remained in its proximity until 23 July.

Despite the fact that the crew of both the tracking boat and the caretakers' boat reacted the same way to Keiko's approaches (i.e., by going below deck and ignoring him), Keiko remained for much longer periods of time by the caretakers' boat, suggesting that he was more strongly attached to it (or to its crew) than to the tracking boat. When Keiko arrived in Norway in period 4, he actively sought out human company, swimming to boats and people. To begin with he was very active, though staying near the surface only diving for $0-1 \mathrm{~min}$ at a time. After a few days Keiko became inactive staying near a small boat (period 5), possibly to avoid the large and steadily increasing crowd of people, now seeking his attention. The frequency of dives and the number of dives lasting more than 1 min were significantly less during period 5 than during the rest of the study, and all other parameters showed the lowest levels of activity during this period. The lack of activity was also evident from visual observations, and possible explanations, not necessarily mutually exclusive, include: stress triggered by the extremely high rate of interactions with people during period 4, physical exhaustion or an infection. A moderately high white cell count from a blood sample taken during period 5 supports the suspected infection. ${ }^{3}$ Alternatively, the white cell count could have been due to dehydration caused by lack of food. At the end of period 5 and during period 6, when professional caretakers took charge of Keiko, his diving parameters began to approach levels similar to those measured at the start of the study.

\section{EvaLUATION AND CONCLUSIONS}

A release program can be considered a success when the released animal is able to feed, maintain health and stress levels comparable to his wild conspecifics, show

\footnotetext{
${ }^{3}$ Personal communication from Colin Baird, Noble Caledonia Limited, 2 Chester Close, Belgravia, London SW1X 7BE, U.K., e-mail: colinbaird@hotmail.com, September 2002.
} 
normal predator avoidance behavior, and ultimately reproduce (unless unable for other reasons, such as reproductive senescence). Under these criteria, Keiko's release to the wild was not successful, since though physically unrestricted and free to leave, he kept returning to his caretakers for food and company.

Two bottlenose dolphins were released in Florida in 1990 and resighted continuously until at least 1996 (Wells et al. 1998). Based on this successful release, Wells et al. (1998) listed several recommendations, some of which can be summarized as follows: (1) release more than one animal together in a social functional unit; (2) released animals should be young of age; (3) release short-term captive animals; (4) keep animals in acclimatizing pen before release; (5) release in native waters; (6) locate sources of live prey for readaptation; (7) study ranging and social association patterns in host community before, during, and after release; and (8) study behavior of released animals before, during, and after release. Keiko's release effort fulfilled to some extent recommendations $4-8$, but failed to fulfill recommendations 1, 2, and 3; Keiko was not part of a killer whale social unit, he was not young, and he had been in captivity for the majority of his life.

Wells et al.'s (1998) recommendations were made for bottlenose dolphins, generally living in fission-fusion societies (Wells 1991), and additional factors may need to be taken into account when considering release of captive killer whales. The best-studied killer whale populations form strongly bonded matriarchal family groups throughout life (e.g., Bigg et al. 1990, Baird and Dill 1996), that forage cooperatively (Similä and Ugarte 1993). Even the males keep strong bonds with their close relatives, communicating with a group-specific repertoire of calls and whistles (Ford 1991, Strager 1995, Ford and Ellis 1999, Riesch et al. 2006). Thus the survival of a released captive killer whale might depend on an adoption to a wild group of killer whales. The successful reintroduction of a North Pacific northern resident killer whale A73 (called Springer) in 2002, demonstrates that killer whales can re-bond after at least a relatively short period of separation, even if their mother is no longer present (Francis and Hewlett 2007). Springer was a suitable candidate for release: she was a juvenile, had been under human care for only $1 \mathrm{mo}$, and was released into her well-researched maternal group, at the time when they feed on abundant salmon runs. Springer was captured with the aim of releasing her into her native group, after it was established that she was lost and unable to survive on her own.

Keiko lived in a very small tank in an amusement park in Mexico City when he performed in the 1993 family film Free Willy. Thereafter, there was a strong public pressure to release Keiko to the wild, preferably to his "family" group in Iceland. Keiko was not chosen for release based on his suitability. In retrospect, Keiko was indeed a poor candidate for release, due to the early age of his capture, long history of captivity, prolonged lack of contact with conspecifics, and strong bonds with humans.

The release of Keiko demonstrated that release of long-term captive animals is especially challenging and while we as humans might find it appealing to free a long-term captive animal, the survival and well being of the animal may be severely impacted in doing so.

Through the last decades, several captive dolphins have been released to the wild. The fate of the majority of these animals is unknown, and most of those monitored 
ended up being recaptured and under human care (review in Gales and Waples 1993). Because there is a high risk of not succeeding, Gales and Waples (1993) concluded that it is absolutely necessary to monitor released animals with any technology available, in order to help the animals if they are in distress. Due to the effective VHF and satellite tracking of Keiko after release, his caretakers were able to reestablish contact with him when he showed signs of distress. In agreement with Gales and Waples (1993), this report shows that a combination of VHF and satellite tracking and a contingency plan for return to human care are necessary if the goals of a release project include the long-term well-being of the animal.

\section{ACKNOWLEDGMENTS}

This paper is dedicated to Stephen Claussen, one of Keiko's trainers. The project would not have been possible without the significant early efforts by the Ocean Futures staff led by team leader Jeff Foster from 1997 to 2001 and the staff of the Free Willy/Keiko Foundation, Iceland, directed by field manager Colin Baird and supervised by Charles Vinick. Adam Lalich skippered the tracking boat Vamos. Gisli Vikingsson and Sverrir D. Halldorsson, Icelandic Marine Research Institute, analyzed Keiko's stomach samples. Lars and Anita Lillebø and Frank Haavik, from Halsa County helped establishing the new base for Keiko in Norway. Naomi Rose and Dave Philips encouraged the writing of this work and offered valuable comments to an earlier draft, together with Toni Frohoff, Sharon Young, Paul Spong, Helena Symonds, Robin Baird, and two anonymous reviewers. Craig McCaw and The Humane Society of the United States (HSUS) provided financial support. The Wendy McCaw Foundation supported tag development. The attempt to release Keiko into the wild in 2002 was a joint effort of The HSUS, Ocean Futures, and the Free Willy/Keiko Foundation.

\section{Literature Cited}

AnONYmous. 2000. Reintroduction protocols. The Ocean Futures Society, 325 Chapala Street, Santa Barbara, CA.

ANONYMOUS. 2003. Report of the working group on the assessment of mackerel, horse mackerel, sardine and anchovy. ICES CM/ACFM:06.

Baird, R. W., AND L. M. Dill. 1996. Ecological and social determinants of group size in transient killer whales. Behavioural Ecology 7:408-416.

Barnard, C., Gilbert, F. AND MCGregor, P. 2001. Asking questions in biology: key skills for practical assessments and project work. Pearson Education Limited, Harlow, Essex.

BigG, M. A., P. F. Olesiuk, G. M. Ellis, J. K. B. Ford AND K. C. Balcomb. 1990. Social organization and genealogy of resident killer whales (Orcinus orca) in the coastal waters of British Columbia and Washington State. Report of the International Whaling Commission (Special Issue 12):383-405.

Cornell, L. 2002. News from Keiko's veterinarian. Available at http://www.keiko.com/ news 2.html.

ForD, J. K. B. 1991. Vocal traditions among resident killer whales (Orcinus orca) in coastal waters of British Columbia. Canadian Journal of Zoology 69:1454-1483.

ForD, J. K. B., AND G. M. ElLIS. 1999. Transients, mammal-hunting killer whales. University of Washington Press, Seattle, WA.

Francis, D., AND G. Hewlett. 2007. Operation Orca, Springer, Luna and the struggle to save West Coast killer whales. Harbour Publishing, Madeira Park, BC.

GaLES, N., AND K. WAPLES. 1993. The relationship and release of bottlenose dolphins from Atlantis Marine Park, Western Autralia. Aquatic Mammals 19:49-59. 
Hoelzel, A. R. 2002. Genetic analyses of the Icelandic killer whale stock. Interim report. The Ocean Futures Society, Santa Barbara, CA 93101.

HoYT, E. 1998. Orca: The whale called killer. Camden House, Rochester, NY.

JAKOBSSON, J., AND G. STEFÁnsSON. 1999. Management of summer-spawning herring off Iceland. ICES Journal of Marine Science 56:827-833.

KRUSE, S. 1991. Interactions between killer whales and boats in Johnstone Strait, B.C. Pages 149-159 in K. Pryor and K. S. Norris, eds. Dolphin societies: Discoveries and puzzles. University of California Press, Berkeley, CA.

Reynolds, J. E., R. S. Wells And S. D. Eide. 2000. The bottlenose dolphin, biology and conservation. University Press of Florida, Gainesville, FL.

Riesch, R., J. K. B. Ford AND F. ThOMSEN. 2006. Stability and group specificity of stereotyped whistles in resident killer whales, Orcinus orca, off British Columbia. Animal Behaviour 71:79-91.

SCHORR, J. L. 2002. Ocean Futures Society research status report, March 2002. Report for the Icelandic Marine Research Institute. The Ocean Futures Society, Santa Barbara, CA.

Schorr, J. L., R. W. BAird, J. J. Foster AND M. B. HANSON. 2001. Diving behaviour of fish-eating killer whales off southern Iceland. Poster presented at the 14 th Biennial Conference on the Biology of Marine Mammals, 14-19 December 2003, Greensboro, NC.

SigurJónSSON, J., AND S. LEATHERWOOD. 1988. The Icelandic live-capture fishery for killer whales, 1976-1988. Rit Fiskideilar 11:307-316.

Sigurjónsson, J., T. Lyrholm, S. LeATHERWOOd, E. JónSSON AND G. VÍkingsson. 1988. Photoidentification of killer whales, Orcinus orca, off Iceland, 1981 through 1986. Rit Fiskideilar 11:99-114.

Similë, T., AND F. UGARTE. 1993. Surface and underwater observations of cooperatively feeding killer whales (Orcinus orca) in northern Norway. Canadian Journal of Zoology 71:1494-1499.

Simon, M., M. Wahlberg, F. Ugarte and L. Miller. 2005. Acoustic characteristics of underwater tail slaps used by Norwegian and Icelandic killer whales (Orcinus orca) to debilitate herring (Clupea harengus). Journal of Experimental Biology 208:2459-2466.

Simon, M., F. Ugarte, M. Wahlberg AND L. A. Miller. 2006. Icelandic killer whales Orcinus orca use a pulsed call suitable for manipulating the schooling behaviour of herring Clupea barengus. Bioacoustics 16:57-74.

Simon, M., P. K. MCGregor AND F. Ugarte. 2007. The relationship between the acoustic behaviour and surface activity of killer whales (Orcinus orca) that feed on herring (Clupea harengus). Acta Ethologica 10:47-53.

STRAGER, H. 1995. Pod-specific call repertoires and compound calls of killer whales, Orcinus orca Linnaeus, 1758, in the waters of northern Norway. Canadian Journal of Zoology 73:1037-1047.

Veit, F., E. Bojanowski, D. Todt, R. Zilber, A. Y. Supin and L. M. Mukhametov. 1997. Back to the Black: Release of a male bottlenose dolphin in the Black Sea after six years in a semifree enclosure at the Red Sea. European Research on Cetaceans 11:72-75.

WELLS, R. 1991. The role of long-term study in understanding the social structure of a bottlenose dolphin community. Pages 199-225 in K. Pryor and K. S. Norris, eds. Dolphin societies: Discoveries and puzzles. University of California Press, Berkeley, CA.

Wells, R. S., K. Bassos-Hull AND K. S. Norris. 1998. Experimental return to the wild of two bottlenose dolphins. Marine Mammal Science 14:51-71.

Yazdi, P., A. Kilian and B. M. Culik. 1999. Energy expenditure of swimming bottlenose dolphins (Tursiops truncatus). Marine Biology 134:601-607. 